\title{
Evaluasi Program Pembelajaran Metode Ummi dalam Meningkatkan Kemampuan Membaca Al-Qur'an di SMP
}

\author{
${ }^{1}$ Siti Nila Wahyuni, ${ }^{2}$ Nurul Aisyah \\ ${ }^{12}$ Universitas Muhammadiyah Yogyakarta, Indonesia \\ e-mail: wahyunisiti011@gmail.com
}

\begin{abstract}
This research aims to analyze the context, input, process, and product of the Tahfidz AlQur'an program at junior high school. The type of this research is evaluative research with a qualitative approach and use an evaluation model of CIPP (Context, Process, Input, Product) by Stufflebeam. Data collection techniques with observation, interview, and documentation. Analysis of this data using data reduction and conclusion. The results of this study are (1) in the context component, the goals and objectives of the Tahfidz AlQur'an program have been a means category that has a purpose to inculcate the Quranic values and familiarize the atmosphere of the Qur'an in life. (2) in the input, the component shows that the input of teachers, methods, and facilities have a good score, but in teacher input still lack educator to guide tahfidz to be more effective in guiding, while input means to study Tahfidz still less comfortable because there is no place specifically so as not to disturbed student concentration (3) in the process component shows that the implementation schedule is held every day, the target of memorization is 2 juz, but in the achievement of the target, not all student can achieve 2 juz (4) in the product, component shows the results and impact of the Tahfidz program can be categorized well. And the completeness of the achievement of the Tahfidz Al-Qur'an program has a value of $50 \%$ and categorized "means".
\end{abstract}

Keywords: UMMI method; Al-Qur'an learning ability

\section{PENDAHULUAN}

Pendidikan adalah suatu proses pencapaian tujuan, artinya pendidikan berupa serangkaian kegiatan yang bermula dari kondisi-kondisi aktual dari individu yang belajar, tertuju pada pencapaian individu yang diharapkan (Mudyahardjo, 2012). UndangUndang Nomor 20 Tahun 2003 menjelaskan beberapa hal mengenai Sistem Pendidikan Nasional yang wajib kita berikan kepada anak didik sehingga mampu menerima pendidikan sebagaimana peserta didik memiliki hak untuk mendapatkan pendidikan yang layak dan sesuai, sebagaimana dijelaskan dalam UndangUndang Nomor 20 Tahun 2003 yakni sebagai berikut: "UU No 20 Th 2003 menetapkan bahwa sistem pendidikan Nasional berdasarkan Pancasila dan Undang-Undang Dasar Negara Republik Indonesia Tahun 1945 yang berfungsi mengembangkan kemampuan dan membentuk watak serta peradaban bangsa yang bermartabat dalam rangka mencerdaskan kehidupan bangsa, bertujuan untuk berkembangnya potensi peserta didik agar menjadi manusia yang beriman dan bertakwa kepada Tuhan Yang Maha Esa, berakhlak mulia, sehat, berilmu, cakap, kreatif, mandiri, dan menjadi Negara yang demokratis serta bertanggung jawab."

Pendidikan akan berjalan dengan baik apabila peserta didik mampu menjalankan pendidikan sesuai dengan teori pendidikan yang sudah dijelaskan di atas yang maksudnya 
pendidikan yang diperoleh oleh peserta didik mampu dikembangkan secara utuh yakni beriman dan bertakwa kepada Allah SWT.

Pendidikan memiliki tujuan memberdayakan diri manusia. Pendidikan merupakan proses untuk memberikan manusia berbagai macam situasi (Suyomukti, 2015). Pendidikan dalam arti sempit adalah sekolah. Pendidikan adalah pengajaran yang diselenggarakan di sekolah sebagai lembaga tempat mendidik (mengajar). Pendidikan diartikan segala pengaruh yang diberikan sekolah terhadap anak dan remaja (usia sekolah) yang diserahkan ke sekolah supaya anak mempunyai kemampuan kognitif serta memiliki kesiapan mental yang menyeluruh serta sempurna dan mampu memiliki kesadaran untuk maju yang berguna bagi mereka untuk terjun langsung ke masyarakat, menjalin interaksi sosial, dan memiliki serta memikul tanggung jawab mereka sebagai individu maupun sebagai makhluk yang hidup bersosial atau bermasyarakat (Suyomukti, 2015).

Dalam ajaran Islam terdapat pandangan yang universal, yaitu bahwa manusia diciptakan oleh Allah sebagai makhluk yang terbaik dan tertinggi/ termulia (Q.S. At-Tin: 5 dan Al-Isra: 70) serta diciptakan dalam kesucian asal (fitrah), sehingga setiap manusia mempunyai potensi benar (Muhaimin, 2004).

Al-Qur'an adalah kalam Allah SWT berupa mukjizat yang diturunkan (diwahyukan) kepada Nabi Muhammad SAW dan membacanya adalah ibadah (Irsyadunnas, 2012). Kitab Al-Qur'an diturunkan kepada Nabi Muhammad SAW yang berisi firmanfirman Allah dan dijadikan sebagai pedoman hidup bagi manusia. Al-Qur'an merupakan kebenaran yang absolut, dimana Al-Qur'an merupakan bukan sebuah pedoman yang biasa dapat diabaikan bagi orang-orang yang ingin mencari kebenaran secara objektif, (Husnel Anwar Matondang, 2013). Selain itu AlQur'an juga dijadikan sebagai pegangan hidup manusia umat Islam sedunia yang diturunkan kepada Rasulullah SAW untuk seluruh umat manusia. Al-Qur'an akan menuntun manusia kepada kebahagiaan yang sesungguhnya yaitu bahagia di dunia dan bahagia di akhirat serta mencakup seluruh aspek pengetahuan.
Umat Islam meyakini bahwa Al-Qur'an adalah kitabullah yang datang dari Allah dan berisi petunjuk-petunjuk serta pedoman yang lengkap. Al-Qur'an merupakan sebuah petunjuk yang memiliki tingkat kesempurnaan yang tinggi, hal tersebut dikarenakan didalamnya terdapat aspek-aspek yang menjadi suatu kebutuhan manusia itu sendiri seperti aqidah (ideologi), akhlaq (moral), ibadah, muamalah dan aturan-aturan yang menghubungkan antara manusia dengan penciptaNya (Tantawi, 2014).

Al-Qur'an yakni kitab Suci yang di mukjizatkan kepada Nabi Muhammad SAW melalui perantara malaikat Jibril yang diturunkan dengan cara berangsur-angsur. Allah senantiasa menyuruh agar sebagai seorang muslim seharusnya melaksanakan segala perintah-perintahnya serta menerapkan hukum-hukumnya dan bisa menjadikannya sebagai penolong bagi orang yang meminta pertolongan, memberikan petunjuk bagi orangorang yang mencari bimbingan, dan cahaya bagi orang yang memerlukan kejelasan. Sebagai orang muslim wajib bagi kita untuk mengamalkan Al-Qur'an, membacanya saja mendapat pahala apalagi menjadi penghafal Al-Qur'an yang merupakan orang pilihan Allah SWT.

Al-Qur'an banyak memberikan pelajaran kepada umat manusia, Al-Qur'an mengajarkan tentang aqidah dan tauhid. Al-Qur'an juga yang mengajarkan manusia tentang cara beribadah kepada Allah. Tidak heran apabila Al-Qur'an disebut sebagai dunia dimana seorang Muslim hidup. Buktinya, ketika umat manusia lahir kemuka bumi ini ditelinganya dibisikkan syahadat yang terdapat di dalam AlQur'an. Kemudian ketika hidup ia mengulangulang bacaan Al-Qur'an disetiap sholat yang dilakukan setiap hari. Dimana sholat merupakan ibadah wajib bagi setiap umat Muslim. Hingga ketika ajalnya sudah tiba ia akan mengakhiri hidupnya dengan syahadat. Oleh karena itu, Al-Qur'an senantiasa dibaca oleh umat manusia. Hampir semua aspek kehidupan manusia merajuk pada Al-Qur'an yang kemudian berpengaruh sangat luas terhadap kehidupan manusia. Seseorang yang dapat mengamalkan ajaran Islam manakala ia mengetahui sumber dari ajaran-ajaran islam tersebut yakni Al-Qur'an. Umat Islam yang 
berpegang teguh terhadap Al-Qur'an tidak akan sesat dan binasa selama-lamanya.

Pentingnya pengetahuan tentang cara membaca Al-Qur'an yang benar sesuai kaidahnya harus dimulai sejak dini. Bagi lembaga pendidikan yang sudah berupaya dalam memecahkan masalah tersebut salah satunya adalah dengan mengadakan program Baca Tulis Al-Qur'an (BTA). Selain itu, program Tahfidz juga menjadi salah satu solusi sebagai pembimbing siswa dalam mempelajari A-Qur'an sebagai bentuk tanggungjawab dalam membentuk generasi muda Qur'ani yang akan mengisi pembangunan bangsa ini.

Dalam rangka mengamalkan ilmu AlQur'an dan memberikan ilmu tentang tata cara membaca serta tantang bagaimana metode menghafal Al-Qur'an yang baik dan tidak menyulitkan bagi para siswa. Lembaga pendidikan Menengah Pertama misalnya SMP Muhammadiyah 1 Gamping yang sudah menerapkan program tahfidz Al-Qur'an sebagai bentuk tanggungjawabnya dalam membentuk generasi muda islam yang berakhlak mulia untuk membangun bangsa di masa yang akan datang, sehingga pihak SMP Muhammadiyah 1 Gamping mengadakan program tersebut sebagai bentuk usaha dalam mewujudkannya. Tahapan tahfidz para siswa akan diperdalam kemampuannya untuk lebih meningkatkan kemampuannya dengan cara menghafal Al-Qur'an. Sehingga dengan adanya program yang mulia ini, diperlukan evaluasi sebagai tolok ukur ketercapaian dari keberhasilan program serta memudahkan dalam mewujudkan dari sebuah tujuan mulia dari program tersebut.

Pendidikan berbasis

Al-Qur'an merupakan pendidikan yang mengupas masalah Al-Qur'an dalam makna; membaca (tilawah), memahami (tadabbur), menghafal (tahfidz) dan mengamalkan serta mengajarkan atau memeliharanya melalui berbagai unsur. Pendidikan Al-Qur'an adalah pendidikan yang menerapkan nilai-nilai yang terkandung dalam Al-Qur'an yang terlihat dalam sikap dan aktivitas peserta didik di manapun dia berada (Zulfitria, 2018).

Al-Qur'an wajib di pelajari oleh seluruh umat manusia dikarenakan Al-Qur'an menyampaikan pesannya yang ditunjukkan kepada semua umat manusia yang dimana manusia memiliki berbeda taraf fikir serta kemampuan akalnya, Al-Qur'an sangat terbuka lebar bagi siapapun yang ingin mempelajarinya karena Al-Qur'an pun dapat memberikan petunjuk dan menjelaskan mana yang benar dan salah. Manusia tidak memiliki kebingungan dalam kehidupan sehari-hari antara lain mengenali hubungan dengan Allah, alam semesta, dan manusia (Thalib, 2015).

Pembelajaran merupakan sebuah proses seseorang dalam belajar. Kata intinya adalah belajar. Menurut pengertian secara psikologi belajar merupakan suatu proses perubahan yakni perubahan mengenai tingkah laku sebagai hasil dari interaksi dengan lingkungan dalam memenuhi kebutuhan hidup (Umar, 2017).Pembelajaran tahfidz merupakan suatu proses mengingat seluruh materi ayat (rincian bagian-bagiannya) yang dihafalkan seperti fonetik, waqaf, dan lain-lain yang dihafalkan dan di ingat secara sempurna tahfidz atau menghafal Al-Qur'an adalah suatu perubahan yang sangat mulia dan terpuji. Sebab, orang yang menghafalkan Al-Qur'an merupakan salah satu hamba yang ahlullah di muka bumi (Wahid, 2014).

\section{METODE}

Penelitian ini merupakan penelitian kualitatif dengan bentuk deskriptif. Penelitian kualitatif adalah penelitian yang berangkat dari inkuiri naturalistik yang temuan-temuannya tidak diperoleh dari prosedur perhitungan secara statistik (Khilmiyah, 2016). Pada penelitian ini menggunakan jenis penelitian evaluasi program (evaluative). Evaluasi program adalah sebuah upaya yang digunakan untuk mengetahui efektifitas komponen program dalam mendukung pencapaian dari tujuan program yang telah dilaksanakan (Arikunto, 2014). Kemudian untuk model evaluasi yang digunakan pada penelitian ini adalah menggunakan model evaluasi CIPP. Model evaluasi CIPP ini merupakan model evaluasi yang mengacu terhadap context (konteks), input, process (proses), dan product (produk). Sehingga harapannya dari model evaluasi ini dapat memberikan arahan tentang seberapa jauh kegiatan yang sudah dilaksanakan telah tercapai sesuai dengan rencana yang telah ditetapkan. 


\section{PEMBAHASAN}

\section{Konteks Evaluation}

Program pembelajaran metode UMMI di SMP Muhammadiyah 1 Gamping bertujuan untuk meningkatkan kemampuan membaca AlQuran. Pelaksanaan program tersebut dilaksanakan oleh seluruh siswa kelas VII, VIII dan IX dalam artian program ini wajib bagi kelas VII E dan VIII A.

Tujuan tahfidz di SMP Muhammadiyah 1 Gamping dapat diungkapkan oleh Ibu UR pada tanggal 16 Desember 2019, yaitu: bisa menghafal 2 juz dalam waktu tempo 3 tahun (tidak ideal) yang terpenting dalam membaca al-quran tidak hanya sekedar membaca. Anak bisa mengetahui aturan membaca yang sesuai dengan tajwid, tahsin, dan makhraj dalam membaca al-qur'an yang berkualitas selama ini. Selama ini memakai metode iqro' sangat kurang bagus bacaannya.

Sehingga dari hasil wawancara tersebut dapat diketahui bahwa program tahfidz tersebut memiliki tujuan yang sangat baik untuk meningkatkan bacaan Al-Quran anak dalam kurun waktu 3 tahun bisa menghafal 2 juz. Mereka belum bisa mengetahui aturan membaca al-qur'an yang baik dan benar sesuai dengan tajwid, tahsin dan makhrajnya. Dengan diadakan program ini, anak-anak mampu mengetahui seberapa tingkat kesulitan dalam membaca Al-Quran dengan didasari oleh kualitas yang dipakai. Tujuannya adalah upaya sekolah dalam meningkatkan kualitas siswa serta bentuk upaya agar anak mencintai AlQuran dan menguasainya ilmunya. Pembelajaran ini diwajibkan bagi siswa kelas VII E dan VIII A, 2 kelas yang diajarkan dari 15 kelas yang ada. Kemudian yang lain juga diajarkan dengan metode iqro' yang mungkin kualitasnya masih dibawah dan untuk hafalan kami mengajarkan 15 juz amma. Tujuannya agar kedepannya menjadikan penerus generasi yang berkualitas hafalannya.

Salah satu yang mendukung dari program ini adalah dengan disediakan guru khusus yang sudah mempunyai sertifikat resmi dari lembaga UMMI yang benar-benar bacaannya sudah memenuhi kriteria. Dengan harapan dapat memaksimalkan dalam pelaksanaan program tahfidz bagi siswa yang memiliki kemampuan dalam membaca Al-
Quran supaya meningkatkan kemampuan sekaligus bentuk pembibitan generasi dimasa yang akan datang.

Program tahfidz ini dilatarbelakangi oleh sekolah muhammadiyah dengan ijin khusus untuk mengembangkan ISMUBA. Maksud kami bisa sejalan dengan visi dan misi kita. Sesuai pembelajaran tahfidz Al-Quran. Harapannya bisa menjalankan syariat Islam serta sumber daya yang maju. Pembelajaran Tahfidz Al-Qur'an untuk menambah ilmu penghafal Qur'an bagi siapa saja yang ingin belajar. Bacalah Al-Qur'an seperti menjaga badanmu sendiri. Kutipan wawancara dapat diartikan bahwa adanya koordinasi guru dan orang tua terhadap perkembangan anak didik.

Latar belakang diadakannya program tahfidz ini adalah adanya izin khusus untuk mengembangkan ISMUBA. Dengan berjalannya waktu, program ini berjalan sesuai visi misi kita. Tujuan diadakannya program tahfidz yaitu agar siswa siswi mampu membenarkan bacaannya serta mendapatkan syafaat di hari kiamat kelak dan bisa mengajarkan ilmunya kepada bawahannya. Sehingga siswa siswi lebih dekat dengan AlQur'an dan tidak lupa mengingat Allah.

Analisis evalusi konteks ini, tujuan program ini sudah jelas bahwa ada 2 kelas yang mengikuti program tahfidz. Tujuannya agar siswa siswi mampu membenarkan bacaan dengan baik serta mampu mengamalkan ilmunya kepada bawahannya. Mengetahui tujuan program tahfidz yang dilaksanakan dalam kurun waktu sepekan 4 kali. Hal ini dikemukakan oleh (Zulfitria, 2017) dalam jurnalnya bahwa tujuan utama pembelajaran tahfidz adalah membentuk kepribadian siswa yang tercermin dalam tingkah laku dan pola pikirnya dalam kehidupan sehari-hari. Maka dari itu, pembelajaran tahfidz Al-Qur'an tidak hanya menjadi tanggung jawab guru Tahfidz Al-Qur'an seorang diri, tetapi juga membutuhkan dukungan dari sekolah, masyarakat. Dalam konteks ini, model yang dibangun bukan untuk mereproduksi apa yang telah diajarkan kegiatan intra-kurikuler, yang mengarah pada inefisiensi.

Berdasarkan wawancara dengan salah satu guru tahfidz sekaligus guru SMP yaitu Ibu RZ pada tanggal 5 Desember 2019 menyebutkan bahwa: "Pengajar tahfidz di 
SMP Muhammadiyah 1 Gamping ada 3 yaitu saya, ibu WD dan bapak IJ selaku pengajar dari UMMI. Adanya pelatihan ustadz-ustadzah ini mampu mendapatkan sertifikat".

Berdasarkan hasil wawancara tersebut, maka dapat disimpulkan bahwa pihak sekolah telah membentuk program tahfidz dengan mengundang ustadz-ustadzah dari UMMI Foundation yang telah memiliki sertifikat pengajar khusus. Tujuannya sehingga siswa siswa ini mampu membenarkan makharijul huruf menjadi sempurna dan bagus. Aspek ini bagi siswa yang belum bisa mengaji dan bacaannya kurang bagus, sehingga dengan mengikuti program tahfidz ini mampu membenarkan bacannya.

\section{Input Evaluation (Evaluasi Masukan)}

Sarana dan prasarana ini sebagai pendukung program pembelajaran metode UMMI di sekolah dalam keseharian siswa. Berdasarkan hasil wawancara dengan Ibu UR pada tanggal 11 Desember 2019 sebagai berikut: "Sarana dan Prasarana di SMP Muhammadiyah 1 Gamping ini dalam kondisi baik. Pihak sekolah sudah menyediakan ruangan khusus untuk pembelajaran tahfidz sehingga ruangan cukup nyaman untuk belajar siswa. Siswa dalam menghafal Al-Qur'an dengan nyaman dan baik, isi perkelas terdapat sekitar 12 anak. Siswa diberikan kartu prestasi untuk penunjang hafalan yang diberikan kepada siswa".

Berdasarkan hasil wawancara diperoleh data yang didapatkan peneliti bahwa sarana dan prasarana di SMP Muhammadiyah 1 Gamping digunakan untuk proses belajar mengajar ini sudah sangat memadai.

Dari hasil wawancara peneliti kepada siswa di SMP Muhammadiyah 1 Gamping tentang sarana dan prasarana program adalah: "Ya dari sarana prasarana di sekolah ini sudah baik, harapan saya untuk kedepannya bisa dibuatkan ruangan sendiri sehingga tidak menggunakan ruangan perpustakaan sebagai pembelajaran tahfidz, tetapi ruangan untuk belajar Al-Qur'an supaya nyaman dan kondusif sih menurut saya".

Berdasarkan hasil wawancara tersebut, kekurangannya yaitu pada segi ruangan, yang mana ruangan yang digunakan pembelajaran yaitu ruang perpustakaan. Untuk sarana yang lainnya sudah cukup baik dan sangat sesuai dengan keadaan sekitar.

Pada umumnya, segi input ini dalam program evaluasi di SMP Muhammadiyah 1 Gamping sudah memenuhi aspek guru yang memiliki sertifikat belajar metode UMMI dengan baik, dari siswa dalam kategori cukup baik. Dapat disimpulkan input (masukan) pada program tahfidz di SMP Muhammadiyah 1 Gamping dalam kategori sudah baik.

Buku yang digunakan

Data dokumentasi pada buku yang digunakan menggunakan buku dari lembaga UMMI yang merupakan buku pendamping untuk bisa membantu anak belajar Al-Quran dan bisa lancar membacanya. Berdasarkan wawancara dengan Ibu RZ selaku guru tahfidz pada tanggal 5 Desember 2019 sebagai berikut: "Untuk buku yang digunakan anak-anak menggunakan buku UMMI agar anak bisa mengulang-ulang bacaan supaya lancar dan bisa memudahkan dalam bacaan sehari-hari. Anak mampu menghafalkan lalu disetorkan ke guru tahfidz".

Media

Berdasarkan hasil wawancara dengan Ibu RZ mengenai hal media apa saja yang digunakan sewaktu program tahfidz di SMP Muhammadiyah 1 Gamping sebagai berikut: "Media yang digunakan dalam program tahfidz al-Qur'an, buku ummi, meja, peraga (konsep jilid, alat penunjuk yang lainnya) untuk memotivasi siswa dalam membaca Al-Qur'an.

Dari hasil wawacara mengenai media yang digunakan dalam pelaksanaan program tahfidz bisa diketahui bahwa program ini menggunakan media seperti al-Qur'an, meja, alat peraga, konsepsi jilid serta alat penunjuk untuk mempermudah bacaan serta memotivasi anak supaya tidak jenuh dalam menghafalkan al-Qur'an.

\section{Process Evaluation (Evaluasi Proses)}

Dari proses menghafal itu bagus maka menghafal yang dihasilkan pun juga baik, faktor-faktor yang mempengaruhi implementasi program Tahfidz Qur'an dikelompokkan menjadi dua bagian, yaitu mendukung dan menghambat. Faktor program Tahfidz yang mendukung Al-Qur'an adalah 
minat, motivasi siswa dan guru qiro'ah, sedangkan faktor penghambat pelaksanaan program Tahfidz Qur'an meliputi; kurangnya keterampilan dalam manajemen waktu, kurangnya dukungan dari orang tua, dan lingkungan.

Berdasarkan hasil wawancara kepada Ibu UR yang dilaksanakan pada hari selasa 17 Desember 2019 tentang pelaksanaan program tahfidz di SMP Muhammadiyah 1 Gamping sebagai berikut: "Pelaksanaan program tahfidz ini dilaksanakan sesuai jadwal KBM (kegiatan belajar mengajar) yang telah disusun oleh pihak sekolah. Dimana pelaksanaannya 1 jam pertama 60 menit tahun pertama. Akan tetapi, setelah dievaluasi waktunya kurang. Sehingga yang kelas 7 diberikan waktu 100 menit hasilnya lebih bagus. Dengan menggunakan metode UMMI ini anak-anak menjadikan semangat yang luar biasa (bacaannya) dengan lantang. Jadi siswa tiap pagi melakukan program tahfidz guna untuk memperlancar bacaan supaya lebih bagus, hafalannya banyak, dan adanya koordinasi dengan orang tua'

Berdasarkan hasil wawancara tersebut, dapat disimpulkan bahwa pelaksanaan program tahfidz ini dilakukan seminggu 4 kali dijam yang sama yaitu pagi hari, karena anak-anak masih memiliki semangat yang luar biasa dan memiliki niat yang baik untuk memperlancar bacaannya. Pelaksanaan ini sesuai jam kegiatan belajar mengajar yang sudah disepakati oleh pihak sekolah. Kelas tahfidz memiliki 2 kelas yaitu VII E dan VIII A, itupun dibagi 2 kelas dikategorikan dengan kelas cepat dan kelas lambat yang memiliki kemampuan hafalan Al-Qur'an lebih banyak bagi siswa. Selain itu pelaksanaan tahfidz ini diberikan waktu 80 menit yang dimulai pukul 07.00-08.40 WIB. Pelaksanaannya program tahfidz di SMP Muhammadiyah 1 Gamping ini diikuti oleh kelas VII E dan VIII A.

Berdasarkan Wawancara dengan Ibu RZ mengenai metode yang digunakan untuk program tahfidz ini menggunakan metode ummi: "Metode yang digunakan biasanya yaitu metode ummi yang dimana dimulai dengan murojaah bersama-bersama. Kemudian dilanjutkan membaca satu persatu lalu disetorkan" (Wawancara dilakukan pada tanggal 5 Desember 2019).

\section{Product Evaluation (Evaluasi produk/hasil)}

Evaluasi produk ini merupakan hasil program tahfidz al-Qur'an. Maksudnya adalah untuk mengetahui sejauh mana hasil yang diraih ketika sudah mengikuti program tahfidz yang diadakan di sekolah untuk mampu menambah bacaan yang kurang fasih.

Hasil wawancara dengan Ibu WD dari lembaga UMMI pada tanggal 18 Februari 2020 sebagai berikut: "Penilaian Tahfidz di SMP Muhammadiyah 1 Gamping ini dengan menggunakan sistem menghafal Al-Qur'an dengan cara menyimak temannya jika ada yang salah lalu dibenarkan. Sistem penilaiannya jika mendapat nilai B itu paling rendah, kebanyakan nilai $\mathrm{B}+$ ".

Berdasarkan hasil wawancara langsung dengan kepala sekolah Ibu UR memperoleh keterangan sebagai berikut: "Untuk kelas 8 tahun pertama memang belum bisa 1 juz (input), karena baru belajar pengucapan. Dalam bacaannya sudah bagus dan lancar, tinggal yang hafalannya. Untuk kelas 7 tambah lebih bagus lagi dan pengaturan durasi waktunya juga lebih panjang sehingga kebetulan anaknya memiliki niatan yang sangat baik, semangatnya pun ada" (Wawancara dilaksanakan tanggal 17 Desember19).

Wawancara selanjutnya dengan guru tahfidz di SMP Muhammadiyah 1 Gamping memperoleh hasil yang sama Berikut hasil wawancara dengan Ibu RZ selaku koordinator program tahfidz di SMP Muhammadiyah 1 Gamping:

Hasil pencapaian masing-masing anak dalam hal makharijul huruf sudah cukup luar biasa, tajwidnya pun sudah bagus. Bahkan anak-anak sudah membenarkan bacaan orang tua dirumah. Dalam hal ini anak-anak mulai bisa menyimak bacaan orang tua ketika membaca al-Qur'an dirumah dengan baik dan benar. Orang tua pun sangat senang anaknya belajar tahfidz di sekolah, semangat dalam hal memotivasi anak mendukung salah satu program sekolah yang sudah berjalan 2 tahun ini.

Berdasarkan hasil wawancara secara langsung oleh pihak sekolah, dapat disimpulkan bahwa program tahfidz ini yang telah diselenggarakan oleh sekolah mampu memberikan anak belajar makharijul huruf 
dengan benar dan bisa juga membenarkan bacaan orang tua. Walaupun pihak sekolah terutama ustadz-ustadzah sudah berusaha membenarkan bacaan siswa, namun ada beberapa yang masih terbata-bata dalam membaca al-Qur'an. Dalam hal ini juga ada wawancara secara langsung dengan siswa mengatakan bahwa dia pernah mengalami kesulitan dalam huruf hijaiyah.

\section{KESIMPULAN}

Dari hasil penelitian dan pembahasan kami tentang evaluasi program tahfidz AlQur'an yang dijalankan di SMP Muhammadiyah 1 Gamping sebagaimana berikut: 1) Evaluasi contex (konteks) menjelaskan dalam program tahfidz di sekolah ini sudah mencapai $70 \%$ sudah baik dalam bacaan makharijul hurufnya, ada beberapa anak yang masih belum lancar bacaannya seperti makhraj yang masih terbata-bata sehingga belum mencapai kemaksimalan yang cukup. Seperti tempat yang sangat terbatas sebagai alat untuk mendukung pelaksanaannya. Dukungan orang tua yang sangat baik, kemampuan siswa yang sudah cukup lancar dibanding tahun pertama; 2) Evaluasi input (masukan) bahwa pihak sekolah dan seluruh anggota guru sudah mengetahui adanya program tahfidz di sekolah. Dari sekolah sudah membagi terdiri dari 2 kelas masing-masing kelas VII E dan VIII A yang dimana dikelompokkan menjadi 2 kelas (kelas cepat dan kelas lambat). Selanjutnya peraturan sudah sangat baik dan hanya perlu pengawasan yang lebih baik lagi supaya bisa dicapai dengan hasil yang baik. Sarana dan prasarana yang belum mencukupi, dan harapan kedepannya semua kelas bisa mengikuti program tahfidz ini; 3) Evaluasi process (hasil) pada pelaksanaan program ini disesuaikan dengan jadwal kegiatan belajar mengajar, dengan waktu 1 jam pertama 60 menit di tahun pertama mulai. Setelah dievaluasi ternyata waktunya sangat kurang, sehingga tidak efektif dalam menjalankan program ini, ada tambahan waktu menjadi 100 menit ternyata hasilnya lebih bagus daripada tahun pertama. Koordinasi ke orang tua juga sangat mendukung akan keberhasilan program yang telah dicapai. Karena setiap paginya murojaah bersama sebelum pelajaran dimulai. Media sudah cukup baik untuk mendukung pelaksanaan program tersebut; 4) Hasil dari evaluasi program ini siswa mampu belajar makharijul huruf dengan lancar, namun juga ada yang belum lancar bacaannya. Dari hasil wawancara bahwa tingkat keberhasilan anak sudah mencapai $70 \%$ namun masih ada yang belum lancar ketika membaca. Akan tetapi, anak memiliki niat yang sangat bagus supaya bisa mendalami al-Qur'an dan artinya. Berhasilnya program tersebut anak mampu membenarkan bacaan orang tua ketika masih banyak yang kurang sesuai dengan makharijul huruf. Hasil pengamatan lapangan yang telah dilakukan terlihat bahwa jalannya program tahfidz ini sudah lumayan bagus.

Secara keseluruhan untuk penilaian terhadap program tahfidz di SMP Muhammadiyah 1 Gamping Yogyakarta, peneliti mendapatkan hasil penelitian bahwa dari aspek context nilainya baik, aspek input cukup baik, aspek prosess cukup baik, dan dari aspek product cukup baik. 1) Dalam aspek konteks, Pada awalnya, pihak sekolah bingung untuk memilih program unggulan karena selama ini program unggulannya bola volly dan memang sering jadi juara baik ditingkat korwil, kabupaten, maupun ke provinsi. Ada beberapa anak sebelum sekolah lain ada kelas olahraga. Setelah ada kelas olahraga kami pun semakin surut. Kemudian kami mencoba untuk mencari terobosan karena sekolah Muhammadiyah berbasis religiusitas maka diganti dengan program unggulan ismuba Tahfidz; 2) Dalam aspek input, pertama yang perlu diperbaiki yaitu pelatihan lebih digalakkan karena itu untuk meningkatkan kemampuan serta kualitas guru tahfidz ketika menyampaikan bacaan yang sesuai dengan pedoman didalam buku. Kedua, kelas tahfidz ini sebenarnya buat yang sudah benar-benar bisa atau yang belum bisa, karena saya memperhatikan ada beberapa yang belum bisa mengikuti bacaan dengan baik seperti temantemannya. Kualitas siswa harus paham bacaan supaya bisa memperlancar sesuai makhrajnya. Sarana dan prasarana seharusnya dibuatkan gedung sendiri agar bisa fokus ketika pembelajaran tahfidz dimulai. Jadi tidak menganggu pengunjung perpustakaan sekolah dan menjadikan siswa semangat dalam menghafal Al-Qur'an dan 3) Dalam segi 
proses, pembelajaran seharusnya diberikan media visual, audio visual supaya meningkatkan pembelajaran Tahfidz akan menjadi menarik dan bagus. Menjadikan anakanak semangat dalam menghafal serta motivasi yang kuat dan dukungan dari sekolah. Ketika pembelajaran bisa ada variasi secara tidak langsung bisa memahami materi pembelajaran dengan sistematis. Dengan adanya media yang menarik, siswa akan lebih memperhatikan bacaan Al-Qur'an yang sesuai dengan pedoman dalam penilaian; serta 4) Aspek product (hasil) bisa didapatkan dalam hal membaca serta menghafalkan Al-Qur'an siswa juga bisa memahami bacaan dengan benar, sehingga siswa akan paham betul dengan isi yang sudah ada dalam kandungan Al-Qur'an.

\section{REFERENSI}

Arikunto, S. \& C. S. A. J. (2014). Evaluasi Program Pendidikan, Pedoman Teoritis Praktis bagi Praktisi Pendidikan. Jakarta: PT. Bumi Aksara.

Husnel Anwar Matondang, S. E. (2013). Alqur'an dan Sains (Suatu Sudut Pandang Terhadap Legalitas Penafsiran Sains Atas Al-Qur'an). Journal Polingua: Scientific Journal of Linguistics, Literature and Education, 2(1).

Irsyadunnas. (2012). Studi Al-Qur'an \& Hadist. Yogyakarta: Kopertais Wilayah III UIN Sunan Kalijaga Yogyakarta.

Khilmiyah, A. (2016). Metode Penelitian Kualitatif. Yogyakarta: Samudra Biru.

Mudyahardjo, R. (2012). Pengantar Pendidikan. Jakarta: PT. Raja Grafindo Persada.

Muhaimin. (2004). Wacana Pengembangan Pendidikan Islam. Yogyakarta: Pustaka Pelajar.

Suyomukti, N. (2015). Teori-Teori Pendidikan Pendekatan Tradisional, (Neo) liberal, Marxis-Sosialis, Hingga Postmodern. Yogyakarta: Ar-Ruzz Media.

Tantawi, I. (2014). Bahasa Indonesia Akademik. Bandung: Cita Pustaka Media.

Thalib, M. (2015). Al-Qur'an dan Filsafat Kehidupan. Yogyakarta: MU Media.

Umar. (2017). Implementasi Pembelajaran Tahfidz Al-Qur'an di SMP Luqman AlHakim. Jurnal Pendidikan Islam, 6(1).

Wahid, W. A. (2014). Cara Cepat Bisa
Menghafal al-Qur'an. Yogyakarta: Diva Press.

Zulfitria. (2017). Peranan Pembelajaran Tahfidz Al-Qur'an dalam Pendidikan karakter di Sekolah Dasar. Jurnal Kajian Penelitian Pendidikan Dan Pembelajaran, 1(2).

Zulfitria. (2018). PERAN PEMBELAJARAN TAHFIDZ AL-QURAN DALAM PENDIDIKAN KARAKTER SISWA. Prosiding Seminar Nasional Pendidikan, 1(1). 